\title{
Gas bubbles in the pericardium and concomitant tricuspid valve mass
}

\author{
Paweł Rostoff ${ }^{1}$, Małgorzata Poręba ${ }^{1}$, Aleksander Siniarski ${ }^{1}$, \\ Patrycja Pikul², Jadwiga Nessler ${ }^{1}$, Grzegorz Gajos ${ }^{1}$ \\ 1 Department of Coronary Disease and Heart Failure, Faculty of Medicine, Jagiellonian University Medical College, The John Paul II Hospital, Kraków, Poland \\ 2 Department of Diagnostics, The John Paul II Hospital, Kraków, Poland
}

Correspondence to: Pawel Rostoff, MD, PhD, Oddział Kliniczny Choroby Wieńcowej i Niewydolności Serca z Pododziałem Intensywnego Nadzoru Kardiologicznego, Wydział Lekarski, Uniwersytet Jagielloński, Collegium Medicum, Krakowski Szpital Specjalistyczny im. Jana Pawła II, ul. Prądnicka 80, 31-202 Kraków Poland, phone: +481261422 18, e-mail: pawel.rostoff@uj.edu.pl Received: April 12, 2017 Revision accepted: April 19, 2017 Published online: April 27, 2017. Conflict of interests: none declared Pol Arch Intern Med. 2017; 127 (4): 283-284 doi:10.20452/pamw.4012 Copyright by Medycyna Praktyczna, Kraków 2017
A 62-year-old man, a heavy smoker with a history of chronic heart failure (New York Heart Association class II), coronary artery disease, hypertension, and chronic obstructive pulmonary disease (COPD), was admitted to the emergency department due to severe dyspnea at rest, pleuritic chest pain, and fatigue. A clinical examination revealed acute decompensated heart failure triggered by new-onset atrial fibrillation with a ventricular rate from 130 to $160 \mathrm{bpm}$ and community-acquired pneumonia.

Chest X-ray and computed tomography (CT) revealed left lower lobe pneumonia with bilateral pleural effusion. Moreover, CT scans showed focal pericardial thickening at the level of the superior cavoatrial junction with gas bubbles within the pericardial inflammatory infiltration (FIgURE 1A). Transthoracic (FIgUre 1B) and transesophageal echocardiography (FIGURE 1C) showed a hyperechogenic, oval, cauliflower-like, nonpedunculated, and mobile mass $(1.5 \times 1.8 \mathrm{~cm}$ in size $)$ attached to the atrial side of the anterior leaflet of the tricuspid valve. Magnetic resonance imaging confirmed the presence of the pathological mass, showing hyperintensity on $\mathrm{T}_{2}$-weighted and inversion recovery sequences (FIGURE 1D).

Multiple blood and sputum cultures were negative. After 2 weeks of empirical antibiotic treatment, the pulmonary and pericardial lesions resolved. The patient underwent a successful tumor resection. The histological findings were consistent with cardiac papillary fibroelastoma. At 12-month follow-up, the patient remained asymptomatic with no recurrence of cardiovascular symptoms.

To the best of our knowledge, this is the first report of acute focal pericarditis with gas formation as a complication of left-sided pleuropneumonia in a patient with papillary fibroelastoma of the tricuspid valve.
The presence of air or gas in the pericardium (pneumopericardium) is mostly associated with blunt or penetrating chest trauma (up to $60 \%$ ) or rarely with barotrauma due to severe asthma or COPD, forceful cough, positive pressure ventilation, repeated vomiting, and cocaine or marijuana use. ${ }^{1}$ Occasionally, it may be related to abnormal communications (fistulas) between the pericardium and air-containing organs/structures (eg, the bronchi, esophagus, lung abscess) or to infectious pericarditis caused by gas-producing pyogenic bacteria (eg, Klebsiella spp., Clostridium spp.). ${ }^{1,2}$ In the preantibiotic era, purulent pericarditis was most frequently a complication of pneumococcal pneumonia. ${ }^{3}$ Nowadays, with early immunization and the widespread use of antibiotics, bacterial pericarditis is an uncommon condition, mainly caused by Staphylococcus aureus and Gram-negative bacteria. ${ }^{3}$

In our patient, the purulent pericarditis was excluded. Furthermore, in typical cases of pneumopericardium, the heart is partially or completely surrounded by air or gas, with the pericardium sharply outlined by air density, ${ }^{4}$ which was not found in our patient. We hypothesized that gas bubbles in the pericardium could be related to focal inflammation of the pericardium caused by gas-producing bacteria that spread via blood or by extension from an adjacent focus of infection in the left lung. The other possible mechanisms include the Macklin effect associated with barotrauma due to severe bout of cough or exacerbation of COPD and/or fistulous communication between the pericardium and infected tissues.

Acute focal pericarditis with gas formation, although extremely rare, should be considered among the cardiovascular complications of pneumonia and possible causes of gas collection in the pericardial cavity. 
FIGURE 1 A -

computed tomography showing focal pericardial thickening at the level of the superior cavoatrial junction with gas bubbles within the pericardial inflammatory infiltration (arrow); B-D transthoracic echocardiography (B), transesophageal echocardiography (C), and magnetic resonance images (D) demonstrating a huge papillary fibroelastoma localized on the tricuspid valve (arrows)
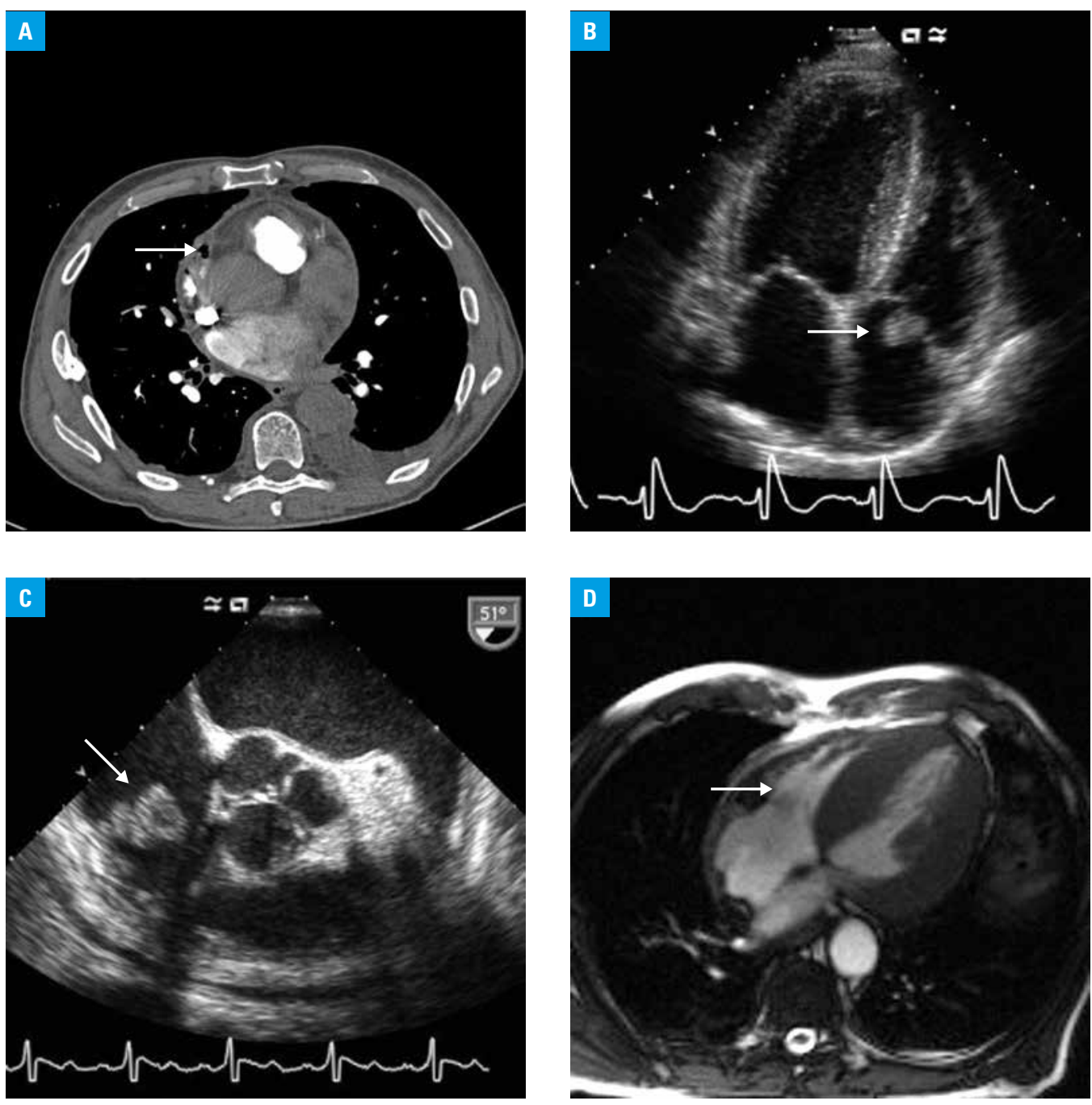

\section{REFERENCES}

1 Gołota JJ, Orłowski T, Iwanowicz K, et al. Air tamponade of the heart. Kardiochir Torakochirurgia Pol. 2016; 13: 150-153.

2 Siniarski A, Rostoff $P$, Laskowicz B, et al. Left circumflex coronary artery aneurysm with arteriovenous fistula to the coronary sinus presenting as acute coronary syndrome. Pol Arch Med Wewn. 2016; 126: 899-900.

3 Held J, Schmitz R, van der Linden M, et al. Purulent pericarditis and pneumonia caused by Streptococcus equi subsp. zooepidemicus. J Med Microbiol. 2014; 63: 313-316.

4 Morimatsu $Y$, Kawano F, Aizawa H. Pneumopericardium following rupture of the oesophagus. Lancet. 2006; 368: 1991. 